\title{
Can environmental pollution by metals change genetic diversity? Ucides cordatus (Linnaeus, 1763) as a study case in Southeastern Brazilian mangroves
}

\author{
Karina Rodrigues da Silva Banci ${ }^{\mathrm{a}}$, Gustavo Maruyama Mori ${ }^{\mathrm{b}}$, Marcos Antonio de Oliveira ${ }^{\mathrm{b}}$, \\ Fernanda Laroza Paganelli ${ }^{\mathrm{c}}$, Mariana Rangel Pereira ${ }^{\mathrm{d}}$, Marcelo Antonio Amaro Pinheiro ${ }^{\mathrm{b}, \mathrm{e}, *}$ \\ a Instituto Butantan - Laboratório de Ecologia e Evolução, Av. Dr. Vital Brasil, 1500, 05503-900 São Paulo (SP), Brazil

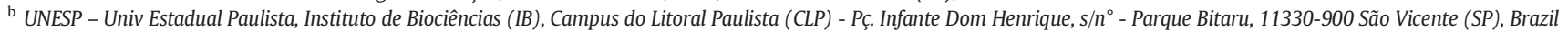 \\ c Programa de Genética e Biologia Molecular (UNICAMP) - Campinas (SP), Brazil \\ d Programa de Biotecnologia (USP) - São Paulo (SP), Brazil \\ e Grupo de Pesquisa em Biologia de Crustáceos (CRUSTA), Brazil
}

\section{A R T I C L E I N F O}

\section{Article history:}

Received 9 July 2016

Received in revised form 13 January 2017

Accepted 19 January 2017

Available online 25 January 2017

\section{Keywords:}

Biomonitoring

Conservation

Crab

Estuary

Metals

Pollution

\begin{abstract}
A B S T R A C T
Industrial areas on estuarine systems are commonly affected by heavy metals, affecting all local biota. Random Amplified Polymorphic DNA (RAPD) was used to evaluate genetic diversity of Ucides cordatus at mangroves in southeastern Brazil (Juréia, J; São Vicente, SV; and Cubatão, C), with distinct pollution levels by metals. The genetic diversity of this species was compared with concentrations of metals $(\mathrm{Cd}, \mathrm{Pb}, \mathrm{Cu}, \mathrm{Cr}$ and $\mathrm{Hg}$ ) in the environment. A pollution gradient was confirmed ( $\mathrm{SV}>\mathrm{C}>\mathrm{J}$ ), with low levels detected in water, except for mercury in SV. All metals in the sediment samples were below Threshold Effect Level (TEL), without an apparent biological risk to the biota. Genetic distance was very similar between J and C, with SV occurring as an out-group. RAPD was a powerful tool to investigate the effect of metal pollution on genetic diversity of this mangrove crab, and to evaluate the conservation status of the mangrove ecosystem.
\end{abstract}

(c) 2017 Elsevier Ltd. All rights reserved.

\section{Introduction}

Mangroves are an ecosystem with intense recycling of nutrients, providing natural nursery grounds for many animal species (e.g. fish, crustaceans and mollusks) (Schaeffer-Novelli, 1995; Spalding, 2012; Lee et al., 2014), and an ideal site for feeding and nesting of birds (Vannucci, 2001; Luther and Greenberg, 2009; Huertas et al., 2016). Biodiversity is relatively low in mangroves, due to physiological adaptations required to support the wide variation of salinity and due to its anoxic/unstable/contaminated sediment (Pinheiro et al., 2008a; Thilagavathi et al., 2013; Remaili et al., 2016).

Recently, mangroves has been purposed to monitor climatic changes (Schaeffer-Novelli et al., 2016), mainly using some species of decapod crustacean that inhabitant this environment (Gilman et al., 2008; Pinheiro \& Almeida, 2015; Siddig et al., 2016). Among these crustaceans Ucides cordatus (Linnaeus, 1763) is an endemic brachyuran that is widely distributed in tropical mangroves of the western Atlantic (Melo, 1996). This species builds its galleries in the sediment and feeds on senescent

\footnotetext{
* Corresponding author at: UNESP - Univ Estadual Paulista, Instituto de Biociências (IB), Campus do Litoral Paulista (CLP) - Pç. Infante Dom Henrique, s/nº - Parque Bitaru, 11330 900 São Vicente (SP), Brazil.

E-mail address: pinheiro@clp.unesp.br (M.A.A. Pinheiro).
}

leaves and propagules present on the substrate (Koch and Nordhaus, 2010; Christofoletti et al., 2013), processing $84 \%$ of the mangrove litter (Koch \& Wolff, 2002). Besides playing a relevant role in carbon cycle by litter processing (Begon et al., 1996; Hogarth, 1999), this crab species is also an important food and subsistence source to coastal communities (Alves \& Nishida, 2003), and has been recently used as bioindicator species for evaluating the conservation status of mangrove areas (Pinheiro et al., 2013). U. cordatus has also been successfully used as a tool to diagnose and classify the human impacts on environmental quality of mangrove ecosystem based on a multi-level analysis (Duarte et al., 2016).

In Brazil, the southeastern coast is the most disturbed, mainly the central coast of the São Paulo State. From this, the Metropolitan Region of 'Baixada Santista' (MRBS) including nine municipalities with around 1.7 million inhabitants (Pinheiro et al., 2008b) stands out. The ecosystems in this coastal region are under significant pressure due to industrial and port activities, with a historic use that dates back $>500$ years (Oliveira et al., 2008). Some estuarine areas (e.g. São Vicente municipality) are characterized by the presence of many stilt houses on the river banks and estuaries (Azevedo et al., 2012), without sanitary condition and correct destination of solid wastes (Cordeiro \& Costa, 2010). While in Brazilian mangroves the main threats are the harvesting of mangrove wood, deforestation for aquaculture ponds, and intense 
property speculation (Macintosh \& Ashton, 2002; Ellison, 2008), at RMBS industrial activities, such as a port complex, prevails, posing an imminent risk, with toxic waste, which may affect the biota (De Wolf et al., 2004). Duarte et al. (2016) quantified and qualified the main pollutants in São Paulo coast areas, with a high concentration of metals and organic contaminants in Central area (where São Vicente and Cubatão are placed) when compared to those registered in South area (where there are conservation units as Juréia).

Several studies have described the effects of pollution on mangrove vegetation (Silva et al., 1990; Arrivabene et al., 2015; Souza et al., 2015) and crustaceans (Harris \& Santos, 2000; Valdovinos \& Zúñiga, 2002; Álvaro et al., 2015), but the use of molecular tools for detecting pollution impacts on the genetic level, particularly in estuarine ecosystem, are scarce. The Random Amplified Polymorphic DNA (RAPD), i.e., is one technique applied in ecotoxicology studies (De Wolf et al., 2004; Giantsis et al., 2012; Liu et al., 2012; Salem et al., 2014; Zhang et al., 2016) for quantification of alleles (bands) and analyses of their addition/loss due to mutation, inversion, deletion or chromosomal rearrangement (De Wolf et al., 2004). This genetic fingerprinting tool is a relatively inexpensive and fast method for evaluating pollutants effects on a broad range of DNA damages, thus, improving environmental risk assessment, mainly in developing countries as Brazil, where this study was carried out.

Our main objective was to evaluate if the presence of heavy metals in environmental matrices (water and sediment) could affect the genetic diversity and structure of the mangrove crab U. cordatus. To this aim, we used Random Amplified Polymorphic DNA (RAPD) technique to assess the genetic variation of $U$. cordatus from three mangrove areas from Southeastern Brazil (Juréia, São Vicente and Cubatão), characterized by distinct pollution levels by metals ( $\mathrm{Cd}, \mathrm{Pb}, \mathrm{Cu}, \mathrm{Cr}$ and $\mathrm{Hg}$ ). A positive association between genetic parameters and concentration of pollutants will allow the use of this tool in studies about environmental conservation, helping government management plans related to the mangrove ecosystem and the target species.

\section{Materials and methods}

\subsection{Study area}

Three mangrove areas, which presumably differ in their degree of environmental impacts, were investigated (Fig. 1) from January to March 2009. Juréia is a legally protected area that composes a great 'Mosaic of Conservation Units' near the mouth of the Una River $\left(24^{\circ} 26^{\prime} 0^{\prime \prime} \mathrm{S}-\right.$ $47^{\circ} 04^{\prime} 5^{\prime \prime} \mathrm{W}$ ), with presence of a traditional community comprising a few people (São Paulo, 2006). São Vicente was represented by a mangrove area near the Branco River $\left(23^{\circ} 56^{\prime} 2^{\prime \prime}\right.$ S $\left.-46^{\circ} 28^{\prime} 1^{\prime \prime} \mathrm{W}\right)$ in São Vicente Municipality, with an impact of 316,324 inhabitants (IBGE, 2010), 11 sources of industrial pollution (Pinheiro et al., 2013), and also impacted. In turn, Cubatão was comprised by a mangrove close to USIMINAS (an important Brazilian steel Company), and adjacent to the Morrões River $\left(23^{\circ} 52^{\prime} 5^{\prime \prime} \mathrm{S}-46^{\circ} 22^{\prime} 2^{\prime \prime} \mathrm{W}\right)$, in Cubatão Municipality, with 116,010 inhabitants (IBGE, 2010). This is one of the largest industrial centers in Brazil (23 industrial complexes, 111 factories, and $>300$
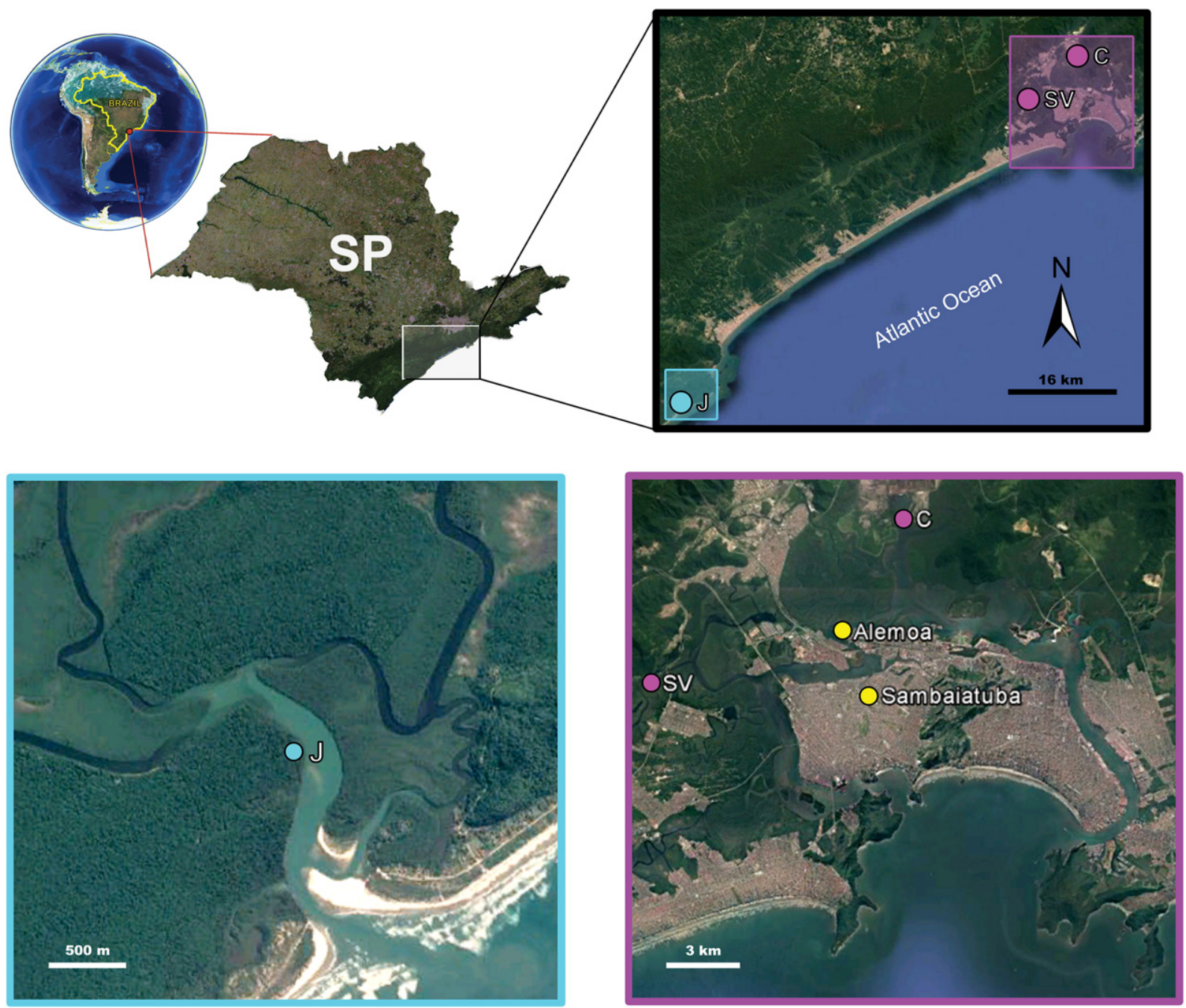

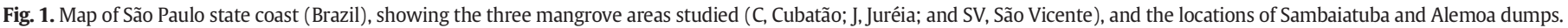


pollution sources, according Pinheiro et al., 2012), that produce fertilizers, steel and petrochemical compounds. In the 1980s, the high pollution at Cubatão was the subject of major global environmental discussions because the incidence of several diseases, most of them linked to genetic mutations (e.g. anencephaly in newborns) (Monteleone-Neto \& Castilla, 1994). Other diffuses sources of pollutants that act in estuarine areas of Central coast of São Paulo state are Sambaiatuba dump $\left(23^{\circ} 55^{\prime} 18^{\prime \prime} \mathrm{S}-46^{\circ} 23^{\prime} 50^{\prime \prime} \mathrm{W}\right)$ and Alemoa dump $\left(23^{\circ} 56^{\prime} 40^{\prime \prime} \mathrm{S}-46^{\circ} 23^{\prime} 11^{\prime \prime} \mathrm{W}\right)$.

\subsection{Metals}

In each mangrove area, we collected three non-adjacent sediment samples at different depths (surface, 15, 30 and $45 \mathrm{~cm}$ ), and three non-contiguous water samples along of a perpendicular transect from the riverbank toward the upper salt flat ("apicum") of the mangroves. The concentrations of five metals $(\mathrm{Cd}, \mathrm{Pb}, \mathrm{Cu}, \mathrm{Cr}$ and $\mathrm{Hg}$ ) from these environmental samples were measured at CEATOX (IB/ UNESP Botucatu) by wet mineralization with $65 \% \mathrm{HNO}_{3}$ (Basset et al., 1981 ) and read by an atomic absorption spectrophotometer (GBC 932 AA) (Athanasopoulos, 1993).

The concentrations of metals in water were compared to reference values for brackish water 'class 1' (minimum human impact), according to National Council of the Environment (CONAMA n ${ }^{\circ} 357 / 2005$, see Table 1). This Brazilian law, however, does not provide the reference values for estuarine sediments (Oliveira et al., 2007). Therefore, these results were compared to guidelines provided by Environment Canada (1999), comprising two categories: 1) Threshold Effect Level (TEL), the concentration below which adverse biological effects are rarely observed $(<10 \%)$; and 2) Probable Effect Level (PEL), the concentration above which adverse biological effects are frequently observed (Table 1 ). We assume that $\mathrm{Cd}, \mathrm{Cr}$, $\mathrm{Cu}, \mathrm{Hg}$ and $\mathrm{Pb}$ are transferred from the environment (water and sediment) to $U$. cordatus (tissues) because there is evidence that the mangrove crab and its main food source may accumulate these heavy metals (Pinheiro et al., 2012). Additionally, U. cordatus individuals from Juréia presented lower frequency of micronucleated cells (Pinheiro et al., 2013; Duarte et al. 2016) and higher neutral red retention time (Duarte et al., 2016) when compared to those sampled in Cubatão and São Vicente.

Data were entered in spreadsheets, and the statistical analyses were conducted using 'R' Version 3.2.3 (R Core Team, 2016). The metal concentrations were first tested for normality (Shapiro-Wilk) and homoscedasticity of the variances (Bartelett's test), which are prerequisites for the application of one- or two-way ANOVA or Student's $t$-test. When the data did not satisfy these prerequisites, the nonparametric Kruskal-Wallis test was applied (Zar, 1999). A statistical level of 5\% was used to evaluate all analyses.

\subsection{Capture of crabs and acquisition of genetic material}

In each mangrove area, 15 specimens of $U$. cordatus were manually collected. All crabs had a cephalothoracic width $(\mathrm{CW})>60 \mathrm{~mm}$, in

\section{Table 1}

Reference values of threshold effect level (TEL) and probable effect level (PEL) for concentrations of metals in sediment and brackish-water 'class 1' (with minimum human impact).

\begin{tabular}{llll}
\hline Metals & \multicolumn{2}{l}{ Sediment $^{\mathrm{a}}(\mu \mathrm{g} / \mathrm{g}=\mathrm{mg} / \mathrm{kg})$} & \\
\cline { 2 - 3 } & TEL & $\begin{array}{l}\text { Brackish water }^{\mathrm{b}} \\
(\mu \mathrm{g} / \mathrm{mL}=\mathrm{mg} / \mathrm{L})\end{array}$ \\
\hline $\mathrm{Cu}$ & 19.0 & 110.0 & 0.005 \\
$\mathrm{Cd}$ & 0.67 & 4.20 & 0.005 \\
$\mathrm{Cr}$ & 52.0 & 160.0 & 0.050 \\
$\mathrm{~Pb}$ & 30.0 & 110.0 & 0.010 \\
$\mathrm{Hg}$ & 0.13 & 0.70 & 0.0002 \\
\hline
\end{tabular}

a Environment Canada (1999).

b National Council of the Environment (CONAMA law n 357/2005). accordance with IBAMA n ${ }^{\circ} 52 / 2003$ (Ibama, 2003). In the laboratory, about $1 \mathrm{~cm}^{3}$ of muscle tissue from the cephalothorax was removed from each animal and placed in Eppendorf tubes $(2 \mathrm{~mL})$ containing absolute ethanol. The tissues were then frozen at $-20{ }^{\circ} \mathrm{C}$ for later molecular analyses.

\subsection{DNA extraction and RAPD technique}

For the extraction of genomic DNA, we followed the protocol described by Sambrook et al. (1989), with adaptations. Muscle tissue (20 mg) from each animal was macerated in liquid nitrogen, under aseptic conditions, and transferred to a $15 \mathrm{~mL}$ tube. A lysis solution was added to each tube, containing $80 \mu \mathrm{L}$ of Proteinase K buffer, $40 \mu \mathrm{L}$ of Proteinase K, $20 \mu \mathrm{L}$ of $20 \%$ SDS and $240 \mu \mathrm{L}$ of ultrapure water. Each tube was then inverted ten times to homogenize the solution with the macerated tissue. The tubes were left in a $60{ }^{\circ} \mathrm{C}$ bath overnight. Next day, the tubes were removed from the bath, and once they reached room temperature, $100 \mu \mathrm{L}$ of $6 \mathrm{M} \mathrm{NaCl}$ was added while the tube was gently shaken. The tubes were then centrifuged at 13,000 rpm at room temperature, for $10 \mathrm{~min}$. The supernatant was recovered and centrifuged once more. The supernatant was recovered again and $1 \mathrm{~V}$ of icecold isopropanol was added. Each tube was inverted for $2 \mathrm{~min}$, and left for $8 \mathrm{~min}$ at room temperature, then centrifuged again at 13,000 rpm at $4{ }^{\circ} \mathrm{C}$ for $15 \mathrm{~min}$. The supernatant was discarded and $1 \mathrm{~mL}$ of ice-cold $70 \%$ ethanol was added. The tubes were centrifuged again at 13,000 rpm, $4{ }^{\circ} \mathrm{C}$ for $5 \mathrm{~min}$. The supernatant was discarded and the pellet was dried at room temperature. The pellet was then resuspended in $100 \mu \mathrm{L}$ of sterilized ultrapure water, and refrigerated $\left(4^{\circ} \mathrm{C}\right)$ for at least $5 \mathrm{~h}$, before being used. The quality of the extracted DNA was evaluated in agarose gel $(0.8 \%)$ stained with ethidium bromide $\left(0.110^{-3} \mathrm{~V}\right)$.

For the RAPD technique, 21 decamer primers of the Eurofins MWG Operon RAPD 10mer Kits were tested for amplification quality, seven of which (OPE12, OPE14, OPE15, OPE18, OPG5, OPI7 and OPJ9; see Table 2) resulted in reliable amplification.

The $20 \mu \mathrm{L}$ polymerase chain reactions (PCR) had the final concentrations: $0.25 \mathrm{mM}$ of dNTP, $1 \times$ reaction buffer, $4 \mathrm{mM}$ of $\mathrm{MgCl}_{2}, 0.1 \mathrm{U} / \mathrm{uL}$ of Taq DNA polymerase, $0.4 \mu \mathrm{M}$ of primer, and $0.4 \mathrm{ng} / \mu \mathrm{L}$ of template DNA (Oliveira-Neto et al., 2007a, b). The thermocycler (MJ-Research, ICNPTC-100-Programmable Thermal Controller) conditions involved initial denaturation for $3 \mathrm{~min}$ at $95^{\circ} \mathrm{C}$, followed by 35 cycles of $15 \mathrm{~s}$. denaturation at $94^{\circ} \mathrm{C}, 30 \mathrm{~s}$. annealing at $35^{\circ} \mathrm{C}, 1 \mathrm{~s}$. extension at $72{ }^{\circ} \mathrm{C}$, and one 4 min cycle at $72{ }^{\circ} \mathrm{C}$ for final extension. We used negative and positive controls in all reactions and each reaction was carried out in duplicate to minimize non-reproducibility issues.

The amplification products were observed in a Gel Doc 1000 gel documentation system (Bio-Rad, Hercules, California, USA), with the software Quantity OneR (Bio-Rad). Based on this gel analysis, binary numerical matrices were constructed ( 0 , absence; 1 , presence) for comparing the bands amplified with each primer. The distance migrated by the fragments ( $\mathrm{mm}$ ) was measured and converted to size in base pairs utilizing the Fragment Size Calculator (available at http://www.basic. northwestern.edu/biotools/SizeCalc.html).

We quantified the genetic diversity using GenAlEx 6.5 (Peakall \& Smouse, 2012) to calculate the following descriptive statistics: number

Table 2

Oligonucleotides used, and their sequences.

\begin{tabular}{ll}
\hline Oligonucleotide & Sequence \\
\hline OPE12 & 5'-TTATCGCCCC-3' \\
OPE14 & 5'-TGCGGCTGAG-3' \\
OPE15 & 5'-ACGCACAACC-3' \\
OPE18 & 5'-GGACTGCAGA-3' \\
OPG5 & 5'-CTGAGACGGA-3' \\
OPI7 & 5'-CAGCGACAAG-3' \\
OPJ9 & 5'-TGAGCCTCAC-3' \\
\hline
\end{tabular}


of bands, number of private bands, percentage of polymorphic loci and unbiased expected heterozygosity $\left(\mathrm{H}_{\mathrm{E}}\right)$ assuming Hardy-Weinberg model for each sampling locality. To describe how the genetic variation is structured, we carried out the Analysis of Molecular Variance (AMOVA: Excoffier et al. 1992) and estimated $\mathrm{F}_{\mathrm{ST}}$ analogue $\left(\Phi_{\mathrm{ST}}\right)$ also using GenAlEx 6.5 (Peakall \& Smouse, 2012) with 9999 permutations for testing the hypothesis that there is no difference among groups. Furthermore, using poppr 2.2.1 (Kamvar et al., 2014), we calculated Nei's genetic distance (1978) among individuals and used Neighbor-Joining (NJ) clustering method (Saitou \& Nei, 1987) with 10,000 bootstrap pseudo-replication to measure branching supports. Finally, we performed a Discriminant Analysis of Principal Components (DAPC; Jombart et al., 2010) to find the number of genetically related individuals that best explain our data and describe the clusters with Bayesian Information Criterion. This method is implemented with adegenet 2.0.1 $R$ package (Jombart, 2008), and it relies on data transformation using Principal Component Analysis (PCA) prior to a Discriminant Analysis (DA) that partitions the genetic variation into between group and within group, maximizing the former (Jombart et al., 2010). To avoid overfitting, we used the function optim.a.score.

\section{Results}

\subsection{Analysis of metals}

Detectable $\mathrm{Pb}$ concentrations in water samples were registered in all mangrove areas with concentrations following a normal tendency (Shapiro-Wilk, $P>0.05$ ), but without difference among mean concentrations when these areas were compared $(t=0.73 ; P=0.51)$ (Table 3$)$. At Juréia, the $\mathrm{Pb}$ concentration in water was $<0.05 \mu \mathrm{g} / \mathrm{mL}$ (estuary and $10 \mathrm{~m}$ from the riverbank), but higher in water samples obtained more internally in mangrove forest $(0.12$ and $0.28 \mu \mathrm{g} / \mathrm{mL}$, with 20 and $30 \mathrm{~m}$ from the riverbank, respectively); in Cubatão $\mathrm{Pb}$ concentrations in water were more homogeneous $(0.12-0.19 \mu \mathrm{g} / \mathrm{mL})$. All the other metals had concentrations below detection limits, both in Juréia and Cubatão ( $\mathrm{Cu}$ and $\mathrm{Cr}:<0.05 ; \mathrm{Cd}:<0.01$; and $\mathrm{Hg}:<0.0001 \mu \mathrm{g} / \mathrm{mL}$ ), except for $\mathrm{Hg}$ in São Vicente $(0.44 \mu \mathrm{g} / \mathrm{mL})$.

Concentration of $\mathrm{Hg}$ in mangrove sediment may be considered absent in all mangrove areas and its strata $(<0.10 \eta \mathrm{g} / \mathrm{g})$. The other registered metals did not have a normal distribution (Shapiro-Wilk, $P<0.05)$, without a significant difference among sediment strata $(0.40<\mathrm{KW}<1.64 ; P>0.41)$ in all mangrove areas (Table 4). Concentrations of $\mathrm{Cu}, \mathrm{Cd}, \mathrm{Cr}$ and $\mathrm{Pb}$ were higher at São Vicente and Cubatão but were similar between them, both contrasting from Juréia (Kruskal-Wallis, $5.81<\mathrm{KW}<16.34 ; P<0.015$ ).

\section{Table 4}

Concentration of metals in water (mean \pm standard error; or $<$ 'value', minimum concentration detected), in mangroves from Juréia, Cubatão and São Vicente, state of São Paulo, Brazil. Means of concentration of $\mathrm{Pb}$ followed by an equal letter did not differ $(P>0.05)$.

\begin{tabular}{llllll}
\hline Mangrove area & \multicolumn{5}{l}{ Metal concentrations $\left(\mathrm{mg} \cdot \mathrm{L}^{-1}\right)$} \\
\cline { 2 - 6 } & $\mathrm{Cu}$ & $\mathrm{Cd}$ & $\mathrm{Cr}$ & $\mathrm{Pb}$ & $\mathrm{Hg}$ \\
\hline Juréia & $<0.05$ & $<0.01$ & $<0.05$ & $0.10 \pm 0.07 \mathrm{a}$ & $<0.10$ \\
Cubatão & $<0.05$ & $<0.01$ & $<0.05$ & $0.15 \pm 0.02 \mathrm{a}$ & $<0.10$ \\
São Vicente & $<0.05$ & $<0.01$ & $<0.05$ & $0.18 \pm 0.07 \mathrm{a}$ & $0.44 \pm 0.00$ \\
\hline
\end{tabular}

\subsection{Analysis of molecular genetic markers}

All seven primers we used reliably amplified a range of 3-8 loci/individual, resulting in an average of seven loci/individual. Overall, we observed $83.78 \%$ of polymorphic bands (considering the entire sampling and all seven primers: $\mathrm{SE}=0.0413$ ) and a low expected heterozygosity $\left(\mathrm{H}_{\mathrm{E}}=0.318, \mathrm{SE}=0.018\right)$. Regarding each population, although we observed that there was no substantial difference on the levels of genetic diversity between the three locations, unexpectedly, samples from Juréia, our reference environment, presented the lowest values for every descriptive statistic we used (Table 5).

We observed the largest amount of the genetic variation within each population (88\%). Despite the low genetic variation between the evaluated populations (12\%), the genetic differentiation between them was significantly higher than expected by chance $\left(\Phi_{\mathrm{ST}}=0.117, P<0.001\right)$. The genetic relation between individuals based on Nei's genetic distance (Nei, 1978) and NJ clustering revealed a complex scenario where individuals from the three sampling locations do not compose well defined (nor statistically supported by the bootstrapping procedure) clades (Fig. $2 A$ ). The genetic structure was better described by using DAPC (Jombart et al., 2010). The number of groups ( $k$ ) that best explained our data was three. The pattern of genetic structure we observed based on two Principal Components that we retained after performing the optim.a.score function suggested that each sampling location is composed of a mixture of genetically distinct individuals (Fig. 2B). Interestingly, most individuals from São Vicente composed one inferred group, and only a few individuals from this location were assigned to the other genetic clusters. These clusters were majoritarily constituted by a mixture of individuals from both Cubatão and Juréia (Fig. 2B).

\section{Discussion}

Mangrove sediments are considered an important geochemical barrier to immobilize pollutants as metals (Neinavaz et al., 2012) due

Table 3

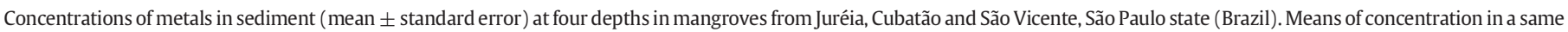
metal followed by an equal letter did not differ $(P>0.05)$.

\begin{tabular}{|c|c|c|c|c|c|c|}
\hline \multirow{3}{*}{$\begin{array}{l}\text { Mangrove } \\
\text { Areas } \\
\text { Juréia }\end{array}$} & \multirow{2}{*}{$\begin{array}{l}\text { Depth } \\
(\mathrm{cm})\end{array}$} & \multicolumn{5}{|c|}{ Metal concentrations $\left(\mu \mathrm{g} \cdot \mathrm{g}^{-1 *}\right.$ and $\left.\eta \mathrm{g} \cdot \mathrm{g}^{-1 * *}\right)$} \\
\hline & & $\mathrm{Cu}^{*}$ & $\mathrm{Cd}^{*}$ & $\mathrm{Cr}^{*}$ & $\mathrm{~Pb}^{*}$ & $\mathrm{Hg}^{* *}$ \\
\hline & Surface & $1.92 \pm 0.12$ & $0.053 \pm 0.003$ & $3.17 \pm 0.17$ & $4.56 \pm 0.14$ & $<0.10$ \\
\hline & 15 & $1.30 \pm 0.17$ & $0.046 \pm 0.003$ & $3.07 \pm 0.61$ & $3.18 \pm 0.25$ & $<0.10$ \\
\hline & 30 & $1.06 \pm 0.12$ & $0.043 \pm 0.003$ & $2.14 \pm 0.17$ & $2.78 \pm 0.53$ & $<0.10$ \\
\hline & 45 & $1.72 \pm 0.45$ & $0.056 \pm 0.007$ & $4.37 \pm 1.33$ & $3.97 \pm 0.85$ & $<0.10$ \\
\hline & Total & $1.39 \pm 0.30 a$ & $0.046 \pm 0.005 a$ & $3.01 \pm 0.79 a$ & $3.30 \pm 0.61 a$ & $<\mathbf{0 . 1 0}$ \\
\hline \multirow{5}{*}{ Cubatão } & Surface & $3.82 \pm 0.37$ & $0.064 \pm 0.009$ & $6.39 \pm 0.74$ & $5.33 \pm 0.53$ & $<0.10$ \\
\hline & 15 & $4.05 \pm 0.22$ & $0.077 \pm 0.013$ & $6.91 \pm 0.40$ & $6.18 \pm 0.53$ & $<0.10$ \\
\hline & 30 & $3.78 \pm 0.21$ & $0.063 \pm 0.009$ & $7.47 \pm 1.25$ & $5.41 \pm 0.21$ & $<0.10$ \\
\hline & 45 & $2.81 \pm 0.49$ & $0.057 \pm 0.009$ & $5.24 \pm 0.97$ & $3.86 \pm 0.95$ & $<0.10$ \\
\hline & Total & $3.30 \pm 0.40 b$ & $0.060 \pm 0.010 \mathrm{ab}$ & $6.05 \pm 0.91 b$ & $4.75 \pm 0.73 a b$ & $<\mathbf{0 . 1 0}$ \\
\hline \multirow[t]{5}{*}{ São Vicente } & Surface & $5.81 \pm 1.28$ & $0.100 \pm 0.023$ & $7.07 \pm 0.45$ & $10.33 \pm 0.56$ & $<0.10$ \\
\hline & 15 & $5.35 \pm 0.34$ & $0.063 \pm 0.003$ & $6.00 \pm 0.80$ & $5.93 \pm 2.98$ & $<0.10$ \\
\hline & 30 & $4.32 \pm 0.18$ & $0.087 \pm 0.007$ & $5.26 \pm 0.69$ & $10.04 \pm 2.11$ & $<0.10$ \\
\hline & 45 & $5.29 \pm 0.69$ & $0.080 \pm 0.010$ & $7.72 \pm 1.73$ & $10.61 \pm 0.30$ & $<0.10$ \\
\hline & Total & $4.81 \pm 0.72 b$ & $0.077 \pm 0.014 b$ & $6.07 \pm 1.05 b$ & $8.31 \pm 1.96 b$ & $<\mathbf{0 . 1 0}$ \\
\hline
\end{tabular}


Table 5

Genetic diversity of Ucides cordatus measured by DNA fingerprinting based on RAPD, with samples from 15 individuals. Where: $\mathrm{H}_{\mathrm{E}}$, heterozygosity; $\mathrm{SE}$, standard error.

\begin{tabular}{llll}
\hline Population & Juréia & Cubatão & São Vicente \\
\hline Number of Bands & 32 & 36 & 34 \\
Number of Private Bands & 0 & 0 & 1 \\
$\mathrm{H}_{\mathrm{E}}( \pm \mathrm{SE})$ & $0.278 \pm 0.033$ & $0.314 \pm 0.030$ & $0.363 \pm 0.029$ \\
Polymorphic Loci $(\%)$ & 75.7 & 89.2 & 86.5 \\
\hline
\end{tabular}

to its high organic matter, cation exchange capacity (CEC), and finer fractions (Faridah-Hanum et al., 2014). The mobility and bioavailability of metals in the environment can be modulated by sorption/desorption and precipitation/dissolution (Skrbic and Djurisic-Mladenovic, 2010). Therefore, in acidic environments occur the weakening of these chemical bonds, a reduction of CEC and release of metals to ground water (Sidi et al., 2015; Ramos et al., 2016), which is specially verified in estuarine areas with a wider range of the salinity (Bryan \& Langston, 1992; Gonçalves \& Carvalho, 2006). Despite the foregoing, in the present study, metal concentrations registered in mangrove sediments were below the Threshold Effect Level (TEL, according Environment Canada, 1999), and are not expected to cause observable adverse effects to the biota. Even though some crustacean species may accumulate metals in a higher concentration in its tissues than in the sediment (Fratini et al., 2008), these damages can be reduced due to metal tolerance, the existence of an efficient detoxification system or by tolerant strains
(Ortega et al., 2016). According to Ahearn et al. (2004), a higher content of metals can be immobilized in hepatopancreas (detoxification organ) of the decapod crustaceans, also occurring in a dissolved form (Wang \& Rainbow, 2005, 2008) or as granules (Corrêa et al., 2002; Corrêa-Junior et al., 2003). However, metal concentrations in this digestive gland may exceed its detoxifying action, so that metals can be registered in other tissues, as in gills, gonads, and musculature (Barrento et al., 2009; Pinheiro et al., 2012).

In São Paulo state (Brazil), Pinheiro et al. (2013) previously verified higher metal concentrations in environmental matrices (water and sediment) in the mangroves of Cubatão when compared to those of Juréia, confirming the better conservation status of this latter and its relevance as ecological station. Moreover, there is a communication between Cubatão and São Vicente at an inner area of the Estuarine System of Santos-São Vicente, sharing the industrial effects and sanitary/waste disposal problems in these municipalities.

It is partially surprising an increasing gradient in pollution levels following the hierarchical order São Vicente (SV) > Cubatão $(\mathrm{C})>$ Juréia $(\mathrm{J})$, since it contrasts with our initial hypothesis that Cubatão was the most polluted mangrove area. All the mangrove areas studied show an extremely low level of metals in water, except for Hg in São Vicente, which had a concentration 2200 times higher than established by legal Brazilian limit. This fact may be explained by an emission source of $\mathrm{Hg}$ near this sampling site. High concentration of some more heavy metallic pollutants dissolved in water (e.g. $\mathrm{Pb}$ and $\mathrm{Hg}$ ), may be increased nearby from domestic sewage and garbage dumps leachate
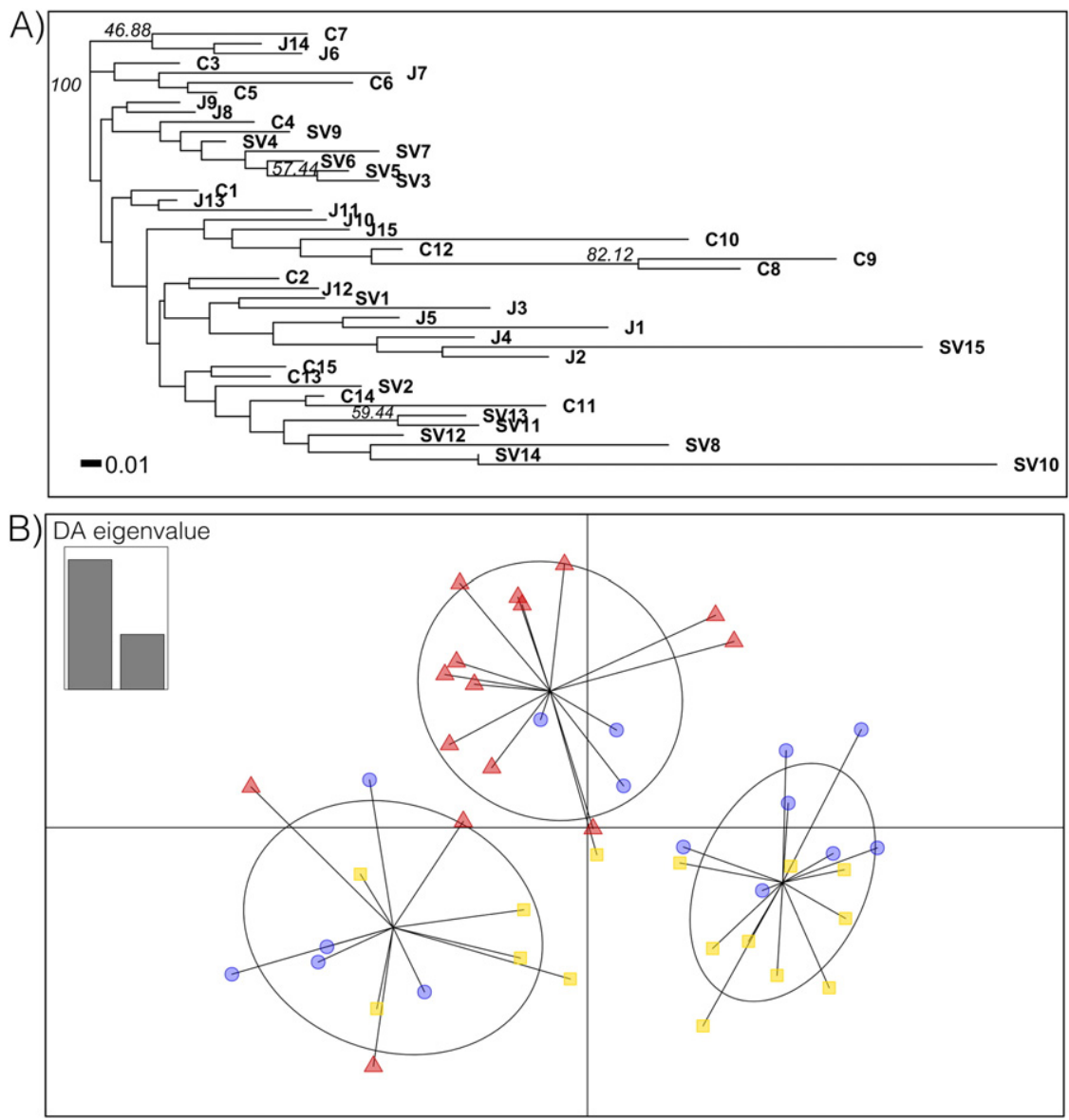

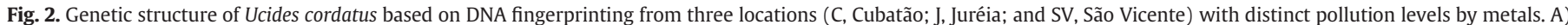

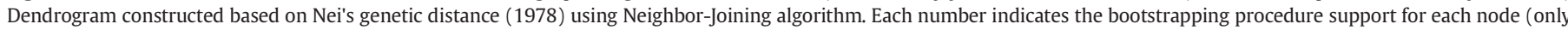

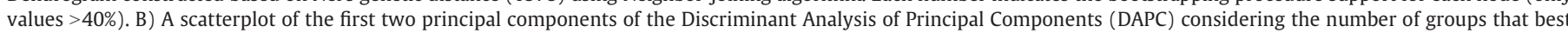

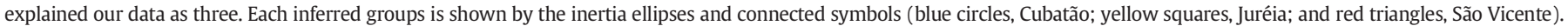


(Sambaiatuba and Alemoa dumps - Fig. 1). According to Christensen et al. (1994) landfill leachate is characterized by some water-based solution of pollutants as heavy metals, with reports confirming higher concentrations near those contaminated sources even after 25 years of interruption of the waste storage activity (CETESB, 2001; Hortellani et al., 2005). To maximize this scenario the region of São Vicente is impacted by carbon processing from metallurgical slag handling (e.g. Branco river), a serious pentachlorophenol record caused by an improper disposal in environment, as well as cyanide, phenolic compounds and other xenobiotics (CETESB, 2001). Otherwise, the valley of Cubatão city was negatively marked by high levels of contamination, and known as 'death valley' in the 60 s, a fact that seems to be reversing since 1984 after the pollution-control program establishment by São Paulo State Environmental Protection Agency - CETESB (Gonçalves et al., 2012).

The concentrations of all the metals measured in this study were below the reference levels, except for Hg in São Vicente. However, some crustacean species may have higher metal concentrations in their tissues than those recorded in their surrounding environment, a fact that highlights the importance of bioaccumulation in these organisms (Ugolini et al., 2004; Remaili et al., 2016). Metal concentrations in tissues and organs of $U$. cordatus from São Vicente were consistently lower than the legal levels according data informed by CETESB (2001), as well as conducted by Pinheiro et al. (2012). Nonetheless, these legal levels of each metal concentration enables the recommended consumption of this fishery resource at Estuarine System of Santos-São Vicente in that moment, a fact not confirmed more recently by Pinheiro et al. (2012). According to these authors in crabs captured in Cubatão mangroves chromium levels in muscle and hepatopancreas were three and six times higher, respectively, than permitted by Brazilian legislation. Manganese concentrations were also high, although a legal contamination limit has not been legally established.

In this study, the genetic diversity descriptive statistics revealed a similar level of genetic variation between the three populations. Contrary to our expectations, Juréia population presented a slightly lower genetic diversity regardless of the statistic analysis considered (Table 5 ). We arbitrarily chose this sampling location to be a reference environment and it indeed presented lower levels of heavy metals. Therefore we expected a higher genetic diversity in the Juréia populations because continuous exposure of animals to xenobiotics may cause a reduction in its genetic variability (Nadig et al., 1998; Ma et al., 2000; Ross et al., 2002; Colin et al., 2016), a process known as "genetic erosion" (Van Straalen \& Timmermans, 2002; Ribeiro \& Lopes, 2013). One process that may explain our result is the increase of the mutation rate by toxic compounds leading to a higher genetic variation in the locations with higher quantities of pollutants, namely São Vicente and Cubatão. The causal relationship between the metals we quantified and an increase in the genetic diversity is a hypothesis worthy of further investigation specifically designed for addressing this issue.

The description of the genetic structure patterns also provided surprising results. We expected to observe one of two contrasting patterns: absence of clear genetic structure, or that individuals from Cubatão and São Vicente (geographically closer locations) would be more related to each other than to those from Juréia. The former was justified by the lack of genetic differentiation of $U$. cordatus at local (within estuary) and regional geographic scales (including populations $3000 \mathrm{~km}$ apart; Oliveira-Neto et al., 2007a, b). The evidence obtained by RAPD and Restriction Fragment Length Polymorphism (Oliveira-Neto et al., 2007a) or by control region of the mitochondrial genome sequence (OliveiraNeto et al., 2007b), genetic markers with different mutation rates and information content (dominant, co-dominant and haplotypes markers), consistently showed that $U$. cordatus populations are genetically homogeneous across a wide range of geographic scales. Conversely, our second expectation followed the rationale of a simple model of isolationby-distance (Wright, 1943) in which due to dispersal limitation, populations could be genetically distinct in a continuously distributed species. Thus, it was also reasonable to expect that geographically closer populations (Cubatão and São Vicente) would be more genetically related when compared to Juréia.

Contrarily to both expectations, we observed a genetic structure pattern in which only individuals from São Vicente composed a relatively delimited group according to our DAPC results (Fig. 2B). This result showed that gene flow indeed is a major biological process for $U$. cordatus, as expected according to previous studies (Oliveira-Neto et al., 2007a, b), since individuals assigned to different genetic clusters are from localities farther than $80 \mathrm{~km}$ apart (Cubatão and Juréia). Additionally, it provided evidence that, at fine geographic scale, there is population differentiation mainly regarding individuals from São Vicente. Considering our data, we are not able to identify specifically the biological processes (fine scale gene flow, natural selection and local adaptation, mutation rate differences - see Gama-Maia and Torres, 2016) that have generated this pattern. For instance, an unforeseen pattern of estuarine water flow, for instance, could lead to the differentiation of São Vicente population and this hypothesis could be tested in future studies using a waterscape genetics approach (Selkoe et al., 2015). Alternatively, a higher mutation rate in São Vicente could explain both the differentiation of the individuals that inhabit this area and the presence of the private band only observed in this location. Thus, one particularly promising hypothesis we consider worthy of being tested is the heavy metals genotoxic effects on $U$. cordatus to evaluate whether the levels of pollutants we observed could lead to higher mutation rates.

The lack of studies concerning metals' accumulation in mangroves biota makes it difficult to elucidate the behavior of these compounds in this estuarine ecosystem, and some of them reveal that mitochondrial DNA and microsatellite techniques can be so informative (Kim et al., 2003; Fratini et al., 2008). According to Pinheiro (unpublished data) high $\mathrm{Hg}$ levels were previously registered in $67 \%$ of the nine mangrove sediment samples from São Vicente, with an average higher than Brazilian reference limits. It may be linked to the accumulation of this metal in hepatopancreas and musculature of the mangrove crab $U$. cordatus and its main food source, the red mangrove (Pinheiro et al., 2012). Register of this metal in water highlights the need for careful monitoring to identify and eliminate pollutant sources.

Moreover our findings also identified an unexpected genetic structure pattern of $U$. cordatus populations, suggesting a complex evolutionary history. We argue that using this crab species as an environment quality indicator considering genetic, physiologic and chemical biomarkers (Pinheiro et al., 2013; Duarte et al., 2016) are a reasonable approach for monitoring. We further confirmed the suitability of genetic markers to investigate the effect of metal pollution on genetic diversity of this mangrove crab and to evaluate environmental remediation measures (Ma et al., 2000; Ross et al., 2002). Finally, we confirmed DNA fingerprinting using RAPD as a particularly interesting method for environmental risk assessment and monitoring, mainly in developing countries as Brazil, due to its relative low cost and fast results.

\section{Acknowledgements}

We thank 'Fundação de Amparo à Pesquisa do Estado de São Paulo' (FAPESP) for awarding financial aid to MAAP during 'Uçá'-Project, Phase II (\#2002/05614-2) and Phase 3 (\#2009/14725-1), to Dr. Alaor A. Almeida (CEATOX - IB/UNESP Botucatu) responsible by metal analysis, and members of Research Group of Crustacean Biology (CRUSTA) for their help during field expeditions in the mangroves. We also thank to Dr. Janet Reid (JWR Associates) that provides the English review service, and to graphic designer Gustavo Pinheiro for the map added to this article. MAAP is grateful to CNPq for the research fellowship provided. 


\section{References}

Ahearn, G.A., Mandal, P.K., Mandal, A., 2004. Mechanisms of heavy-metal sequestration and detoxification in crustaceans: a review. J. Comp. Physiol. B. 174, 439-452.

Álvaro, N.V., Neto, A.I., Couto, R.P., Azevedo, J.M.N., Rodrigues, A.S., 2015. Crabs tell the difference - relating trace metal content with land use and landscape attributes. Chemosphere 144, 1377-1383.

Alves, R.R.N., Nishida, A.K., 2003. Aspectos socioeconômicos e percepção ambiental dos catadores de caranguejo-uçá Ucides cordatus cordatus (L. 1763) (Decapoda, Brachyura) do estuário do Rio Mamanguape, Nordeste do Brasil. Interciencia 28, 36-43.

Arrivabene, H.P., Souza, I.C., Có, W.L.O., Conti, M.M., Wunderlin, D.A., Milanez, C.R.D., 2015. Effect of pollution by particulate iron on the morphoanatomy, histochemistry, and bioaccumulation of three mangrove plant species in Brazil. Chemosphere 127, 27-34.

Athanasopoulos, N., 1993. Flame Methods Manual for Atomic Absorption. GBC Scientific Equipment PTY Ltd., Victoria.

Azevedo, J.S., Hortellani, M.A., Sarkis, J.E.S., 2012. Accumulation and distribution of metals in the tissues of two catfish species from Cananéia and Santos-São Vicente estuaries. Braz. J. Oceanogr. 60, 463-472.

Barrento, S., Marques, A., Teixeira, B., Anacleto, P., Carvalho, M.L., Vaz-Pires, P., Nunes, M.L., 2009. Macro and trace elements in two populations of brown crab Cancer pagurus: ecological and human health implications. J. Food Compos. Anal. 22 (1), 65-71.

Basset, J., Denney, R.C., Jeffery, G.H., Mendhan, J., 1981. Vogel - Análise Inorgânica Quantitativa. fourth ed. Guanabara Dois, Rio de Janeiro.

Begon, M., Harper, J.L., Townsend, C.R., 1996. Ecology. 3th ed. Blackwell Science, London.

Bryan, G.W., Langston, W.J., 1992. Bioavailability, accumulation and effects of heavy metals in sediments with special reference to United Kingdom estuaries: a review. Environ. Pollut. 76, 89-131.

CETESB - Companhia Ambiental do Estado de São Paulo, 2001. Sistema Estuarino de Santos e São Vicente. Programa de Controle de Poluição da Companhia de Tecnologia de Saneamento Ambiental, São Paulo, Brasil [www document]. http://www.acpo.org.br/ biblioteca/06_areas_contaminadas_\%20saturadas/relatorio_sistema_estuarino_ santos_sv.pdf (accessed 02.09.16).

Christensen, T.H., Kjeldsen, P., Albrechtsen, H.-J., Heron, G., Nielsen, P.H., Bjerg, P.L., Holm, P.E., 1994. Attenuation of landfill leachate pollutants in aquifers. Crit. Rev. Environ. Sci. Technol. 24, 119-202.

Christofoletti, R.A., Hattori, G.Y., Pinheiro, M.A.A., 2013. Food selection by a mangrove crab: temporal changes in fasted animals. Hydrobiologia 702, 63-72.

Colin, N., Porte, C., Fernandes, D., Barata, C., Padrós, F., Carrassón, M., Monroy, M., CanoRocabayera, O., de Sostoa, A., Piña, B., Maceda-Veiga, A., 2016. Ecological relevance of biomarkers in monitoring studies of macro-invertebrates and fish in Mediterranean rivers. Sci. Total Environ. 540, 307-323.

CONAMA - Conselho Nacional do Meio Ambiente, 2005. Resolução Conama n 357, de 17 de março de 2005, Diário Oficial da União [www document]. http://www.mma.gov. $\mathrm{br} /$ port/conama/legiabre.cfm?codlegi=459 (accessed 08.01.12).

Cordeiro, C.A.M.M., Costa, T.M., 2010. Evaluation of solid residues removed from a mangrove swamp in the São Vicente Estuary, SP, Brazil. Mar. Pollut. Bull. 60, 1762-1767.

Corrêa, J.D., Farina, M., Allodi, S., 2002. Cytoarchitectural features of Ucides cordatus (Crustacea Decapoda) hepatopancreas: structure and elemental composition of electrondense granules. Tissue Cell 34, 315-325.

Corrêa-Junior, J., Allodi, S., Farina, M., 2003. Enzymatic, analytical and structural aspects of electron-dense granules in cells of Ucides cordatus (Crustacea, Decapoda) hepatopancreas. Cell Tissue Res. 311, 107-116.

De Wolf, H., Blust, R., Backeliau, T., 2004. The use of RAPD in ecotoxicology. Mutat. Res. 566, 249-262.

Duarte, L.F.A., Souza, C.A., Nobre, C.R., Pereira, C.D., Pinheiro, M.A.A., 2016. Multi-level biological responses in Ucides cordatus (Linnaeus, 1763) (Brachyura, Ucididae), as indicators of conservation status in mangrove areas from the Western Atlantic. Ecotoxicol. Environ. Saf. 133, 176v187.

Ellison, A.M., 2008. Managing mangroves with benthic biodiversity in mind: moving beyond roving banditry. J. Sea Res. 59, 2v15.

Environment Canada, 1999. Canadian sediment quality guidelines for the protection of aquatic life. Summary tables. [www document]. http://www.ec.gc.ca (accessed 01.18.10).

Excoffier, L., Smouse, P.E., Quattro, J.M., 1992. Analysis of molecular variance inferred from metric distances among DNA haplotypes: application to human mitochondrial DNA restriction data. Genetics 131, 479-491.

Faridah-Hanum, I., Latiff, A., Hakeem, K.R., Ozturk, M., 2014. Mangrove Ecosystems of Asia: Status, Challenges and Management Strategies. Springer, New York.

Fratini, S., Zane, L., Ragioneri, L., Vannini, M., Cannicci, S., 2008. Relationship between heavy metal accumulation and genetic variability decrease in the intertidal Pachygrapsus marmoratus (Decapoda: Grapsidae). Estuar. Coast. Shelf Sci. 79, 679-686.

Gama-Maia, D.J., Torres, R.A., 2016. Fine scale genetic-structuring, divergent selection, and conservation prospects for the overexploited crab Cardisoma guanhumi in tropical mangroves from Northeastern Brazil. J. Mar. Biol. Assoc. UK 96, 1677-1686.

Giantsis, I.A., Kravva, N., Apostolidis, A.P., 2012. Genetic characterization and evaluation of anthropogenic impacts on genetic patterns in cultured and wild populations of mussels (Mytilus galloprovincialis) from Greece. Genet. Mol. Res. 11, 3814-3823.

Gilman, E.L., Ellison, J., Duke, N.C., Field, C., 2008. Threats to mangroves from climate change and adaptation options: a review. Aquat. Bot. 89, 237-250.

Gonçalves, G.M., Carvalho, C.E.V., 2006. Particulate heavy metal dynamics in a tropical estuary under distinct river discharge and tidal regimes, Southeastern, Brazil. J. Coast. Res. 39, 1032-1035.

Gonçalves, W.F., Luiz-Silva, W., Machado, W., Nizoli, E.C., Santelli, R.E., 2012. Geochemistry of intertidal sediment pore waters from the industrialized Santos-Cubatão Estuarine System, SE Brazil. An. Acad. Bras. Cienc. 84, 427-442.
Harris, R.R., Santos, M.C.F., 2000. Heavy metal contamination and physiological variability in the Brazilian mangrove crabs Ucides cordatus and Callinectes danae (Crustacea: Decapoda). Mar. Biol. 137, 691-703.

Hogarth, P.J., 1999. The Biology of Mangroves. Oxford University Press, Oxford.

Hortellani, M.A., Sarkis, J.E.S., Bonetti, J., Bonetti, C., 2005. Evaluation of mercury contamination in sediments from Santos-São Vicente estuarine system, São Paulo State, Brazil. J. Braz. Chem. Soc. 16, 1140v1149.

Huertas, D., Grimalt, J.O., Jover, L., Sanpera, C., 2016. Influence of diet in the accumulation of organochlorine compounds in herons breeding in remote riverine environments. Chemosphere $145,438-444$.

Ibama - Instituto Nacional do Meio Ambiente e dos Recursos Naturais Renováveis, 2003s. Portaria Ibama $n^{\circ}$ 52, de 30 de setembro de 2003. Diário Oficial da União [www document]. http://www.icmbio.gov.br/cepsul/images/stories/legislacao/Portaria/2003/ p_ibama_52_2003_defesocaranguejouca_se_s.pdf (accessed 01.04.16).

IBGE - Instituto Brasileiro de Geografia e Estatística, 2010. Resolução n 6, de 3 de Novembro de 2010. Diário Oficial a União (DOU), Seção. 1 pp. 104-192.

Jombart, T., 2008. adegenet: a R package for the multivariate analysis of genetic markers Bioinformatics 24, 1403-1405.

Jombart, T., Devillard, S., Balloux, F., 2010. Discriminant analysis of principal components: a new method for the analysis of genetically structured populations. BMC Genet. 11: 94. http://dx.doi.org/10.1186/1471-2156-11-94.

Kamvar, Z.N., Tabima, J.F., Grünwald, N.J., 2014. Poppr: an R package for genetic analysis of populations with clonal, partially clonal, and/or sexual reproduction. PeerJ 2, e281. http://dx.doi.org/10.7717/peerj.281.

Kim, S., Rodriguez, M., Suh, J., Song, J., 2003. Emergent effects of heavy metal pollution at a population level: Littorina brevicula a study case. Mar. Pollut. Bull. 46, 74-80.

Koch, V., Nordhaus, I., 2010. Feeding ecology and ecological role of north Brazilian mangrove crabs. In: Saint-Paul, U., Schneider, H. (Eds.), Mangrove Dynamics and Management in North Brazil. Ecological Studies 211, pp. 265-273.

Koch, V., Wolff, M., 2002. Energy budget and ecological role of mangrove epibenthos in the Caeté estuary, North Brazil. Mar. Ecol. Prog. Ser. 228, 119-130.

Lee, S.Y., Primavera, J.H., Dahdouh-Guebas, F., McKee, K., Bosire, J.O., Cannicci, S., Diele, K Fromard, F., Koedam, N., Marchand, C., Mendelssohn, I., Mukherjee, N., Record, S., 2014. Ecological role and services of tropical mangrove ecosystems: a reassessment. Glob. Ecol. Biogeogr. 23, 726-743.

Liu, W. Sun, L, Zhong M. Zhou, Q Gong Z. Li, P. Tai, P. Li, X 2012. Cadmium-induced DNA damage and mutations in Arabidopsis plantlet shoots identified by DNA fingerprinting. Chemosphere 89 (9), 1048-1055.

Luther, D.A., Greenberg, R., 2009. Mangroves: a global perspective on the evolution and conservation of their terrestrial vertebrates. Bioscience 59, 602-612.

Ma, X.L., Cowles, D.L., Carter, R.L., 2000. Effect of pollution on genetic diversity in the bay mussel Mytilus golloprovincialis and the acorn barnacle Balanus glandula. Mar. Environ. Res. 50, 559-563.

Macintosh, D.J., Ashton, E.C., 2002. A Review of Mangrove Biodiversity Conservation and Management. Centre for Tropical Ecosystems Research. University of Aarhus, Denmark.

Melo, G.A.S., 1996. Manual de Identificação dos Brachyura (caranguejos e siris) do Litora Brasileiro. first ed. Museu de Zoologia da Universidade de São Paulo, São Paulo.

Monteleone-Neto, R., Castilla, E.E., 1994. Apparently normal frequency of congenital anomalies in the highly polluted town of Cubatão, Brazil. Am. J. Med. Genet. 52, 319-323.

Nadig, S.G., Lee, K.L., Adams, S.M., 1998. Evaluating alterations of genetic diversity in sunfish populations exposed to contaminants using RAPD assay. Aquat. Toxicol. 43 163-178.

Nei, M., 1978. Estimation of average heterozygosity and genetic distance from a small number of individuals. Genetics 23, 341-369.

Neinavaz, E., Shirazi, E.K., Emami, B., Dilmaghani, Y., 2012. In: Ishwaran, N. (Ed.), Investigation of Reproductive Birds in Hara Biosphere Reserve, Threats and Management Strategies. Intech Open Access Publisher :pp. 245-260 ([www document]). http://www.intechopen.com/books/the-biosphere/investigationof-reproductive-birds-in-hara-biospherereserve-threats-and-managementstrategies (accessed 01.04.16).

Oliveira, M.L.J., Vidal-Torrado, P., Otero, X.L., Ferreira, J.R., 2007. Mercúrio total em solos de manguezais da Baixada Santista e Ilha do Cardoso, Estado de São Paulo. Quim. Nova 30, 519-524.

Oliveira, A.J.F.C., Pinheiro, M.A.A., Fontes, R.F.C., 2008. Panorama Ambiental da Baixada Santista. first ed. UNESP - Campus Experimental do Litoral Paulista, São Vicente, SP.

Oliveira-Neto, J.F., Boeger, W.A., Pie, M.R., Ostrensky, A., Hungria, D.B., 2007a. Genetic structure of populations of the mangrove crab Ucides cordatus (Decapoda: Ocypodidae) at local and regional scales. Hydrobiologia 583, 69-76.

Oliveira-Neto, J.F., Boeger, W.A., Pie, M.R., Ostrensky, A., Hungria, D.B., 2007b. Population genetics and evolutionary demography of Ucides cordatus (Decapoda: Ocypodidae). Mar. Ecol. 28, 460-469.

Ortega, P., Vitorino, H.A., Moreira, R.G., Pinheiro, M.A.A., Almeida, A.A., Custódio, M.R., Zanotto, F.P., 2016. Physiological differences in the crab Ucides cordatus from two populations inhabiting mangroves with different levels of cadmium contamination. Environ. Toxicol. Chem. 9999:1-11. http://dx.doi.org/10.1002/etc.3537.

Peakall, R., Smouse, P.E., 2012. GenAlEx 6.5: genetic analysis in Excel. Population genetic software for teaching and research - an update. Bioinformatics 28, 2537-2539.

Pinheiro, M.A.A., Almeida, R., 2015. Monitoramento da densidade e da estrutura populacional do caranguejo-uçá, Ucides cordatus (Linnaeus, 1763) (Brachyura: Ucididae). In: Turra, A., Denadai, M.R. (Eds.), Protocolos para o Monitoramento de Habitats Bentônicos Costeiros - Rede de Monitoramento de Habitats Bentônicos Costeiros - ReBentos. Instituto Oceanográfico da Universidade de São Paulo, São Paulo, pp. 122-133.

Pinheiro, M.A.A., Costa, T.M., Gadig, O.B.F., Buchmann, F.S.C., 2008a. Os Ecossistemas Costeiros e sua Biodiversidade na Baixada Santista. In: Oliveira, A.J.F.C., Pinheiro, 
M.A.A., Fontes, R.F.C. (Eds.), Panorama Ambiental da Baixada Santista. UNESP - Campus Experimental do Litoral Paulista, São Vicente.

Pinheiro, M.A.A., Oliveira, A.J.F.C., Fontes, R.F.C., 2008b. Introdução ao Panorama Ambiental da Baixada Santista. In: Oliveira, A.J.F.C., Pinheiro, M.A.A., Fontes, R.F.C. (Eds.), Panorama Ambiental da Baixada Santista. UNESP - Campus Experimental do Litoral Paulista, São Vicente.

Pinheiro, M.A.A., Silva, P.P.G., Duarte, L.F.A., Almeida, A.A., Zanotto, F.P., 2012. Bioaccumulation of a range of metals in the mangrove crab Ucides cordatus (Crustacea: Ucididae) and its food source, the red mangrove Rhizophora mangle (Angiosperma: Rhizophoraceae). Ecotoxicol. Environ. Saf. 81, 114-121.

Pinheiro, M.A.A., Duarte, L.F.A., Toledo, T.R., Adam, M.A., Torres, R.A., 2013. Habitat monitoring and genotoxicity in Ucides cordatus (Crustacea: Ucididae), as tools to manage a mangrove reserve in southeastern Brazil. Environ. Monit. Assess. 185, 8273-8285.

Ramos, A.S., Antunes, S.C., Nunes, B., 2016. Biomonitoring of environmental stress in Pollicipes from the northern coast of Portugal: a non-destructive approach using haemolymph. Ecotoxicol. Environ. Saf. 126:1-13. http://dx.doi.org/10.1016/j.ecoenv. 2015.12.008.

R Core Team, 2016. R: a language and environment for statistical computing. R Foundation for Statistical Computing, Vienna, Austria. [www document]. https://www.Rproject.org/ (accessed 01.04.16).

Remaili, T.M., Simpson, S.L., Amato, E.D., Spadado, D.A., Jarolimek, C.V., Jolley, D.F., 2016 The impact of sediment bioturbation by secondary organisms on metal bioavailability, bioaccumulation and toxicity to target organisms in benthic bioassays: Implications for sediment quality assessment. Environ. Pollut. 208 (Part B), 590-599.

Ribeiro, R., Lopes, I., 2013. Contaminant driven genetic erosion and associated hypotheses on alleles loss, reduced population growth rate and increased susceptibility to future stressors: an essay. Ecotoxicology 22, 889-899.

Ross, K., Cooper, N., Bidwell, J.R., Elder, J., 2002. Genetic diversity and metal tolerance of two marine species: a comparison between populations from contaminated and reference sites. Mar. Pollut. Bull. 44, 671-679.

Saitou, N., Nei, M., 1987. The neighbor-joining method: a new method for reconstructing phylogenetic trees. Mol. Biol. Evol. 4, 406-425.

Salem, Z.B., Capelli, N., Grisey, E., Baurand, P., Ayadi, H., Aleya, L., 2014. First evidence of fish genotoxicity induced by heavy metals from landfill leachates: the advantage of using the RAPD-PCR technique. Ecotoxicol. Environ. Saf. 101, 90-96.

Sambrook, J., Fritsch, E.F., Maniatis, T., 1989. Molecular Cloning: A Laboratory Manual - 2. Eukaryotic Cells. second ed. Cold Spring Harbor Laboratory Press, Cold Spring Harbor.

São Paulo - Governo do Estado de São Paulo, 2006. Lei Estadual n 12.406, de 12 de dezembro de 2006. Diário Oficial do Estado de São Paulo [www document]. http:// www.al.sp.gov.br/repositorio/legislacao/lei/2006/lei-12406-12.12.2006.html (accessed 01.04.16).

Schaeffer-Novelli, Y., 1995. Manguezal: Ecossistema entre a Terra e o Mar. Caribbean Ecological Research, São Paulo.

Schaeffer-Novelli, Y., Soriano-Sierra, E.J., Vale, C.C., Bernini, E., Rovai, A.S., Pinheiro, M.A.A., Schmidt, A.J., Almeida, R., Coelho Jr., C., Menghini, R.P., Martinez, D.I., Abuchahla, G.M.O., Cunha-Lignon, M., Charlier-Sarubo, S., Shirazawa-Freitas, J., Cintrón, G., 2016. Climate changes in mangrove forests and salt marshes. Braz. J. Oceanogr. 64 (sp.2), 37-52.
Selkoe, K.A., Scribner, K.T., Galindo, H.M., 2015. Waterscape genetics applications of landscape genetics to rivers, lakes, and seas. In: Balkenhol, N., Cushman, S.A., Storfer, A.T., Waits, L.P. (Eds.), Landscape Genetics: Concepts, Methods, Applications. John Wiley \& Sons Ltd., Chichester, UK http://dx.doi.org/10.1002/9781118525258.ch13.

Siddig, A.A.H., Ellison, A.M., Ochs, A., Villar-Leeman, C., Lau, M.K., 2016. How do ecologists select and use indicator species to monitor ecological change? Insights from 14 years of publication in ecological indicators. Ecol. Indic. 60, 223-230.

Sidi, N., Aris, A. Z Talib, S. N. Johan, S., Yusoff, T S.T.M. Ismail, MZ 2015. Influential factors on the cation exchange capacity in sediment of Merambong Shoal, Johor. Procedia Environ. Sci. 30, 186-189.

Silva, C.A., Lacerda, L.D., Rezende, C.E., 1990. Metals reservoir in a red mangrove forest. Biotropica 22, 339-345

Skrbic, B., Djurisic-Mladenovic, N., 2010. Chemometric interpretation of heavy metal patterns in soils worldwide. Chemosphere 80, 1360-1369.

Souza, L.D. Rocha, L.D. Morozesk, M., Bonomo, M.M., Arrivabene, H.P., Duarte, I.D. Furlan, L.M., Monferrán, M.V., Mazik, K., Elliott, M., Matsumoto, S.T., Milanez, C.R.D., Wunderlin, D.A., Fernandes, M.N., 2015. Changes in bioaccumulation and translocation patterns between root and leafs of Avicennia schaueriana as adaptive response to different levels of metals in mangrove system. Mar. Pollut. Bull. 94, 176-184.

Spalding, M., 2012. Mangroves: a unique, rare and threatened ecosystem. In: Van Lavieren, H., Spalding, M., Alongi, D.M., Kaihuma, M., Clüsener-Godt, M., Adeel, Z. (Eds.), Securing the Future of Mangroves. UNESCO - United Nations Educational, Scientific and Cultural Organization, Hamilton, pp. 9-12.

Thilagavathi, B., Varadharajan, D., Babu, A., Manoharan, J., Vijayalakshmi, S., Balasubramanian, T., 2013. Distribution and diversity of macrobenthos in different mangrove ecosystems of Tamil Nadu Coast, India. J. Aquac. Res. Dev. 4:199. http:// dx.doi.org/10.4172/2155-9546.1000199.

Ugolini, A., Borghini, F., Calosi, P., Bazzicalupo, M., Chelazzi, G., Focardi, S., 2004. Mediterranean Talitrus saltator (Crustacea, Amphipoda) as a biomonitor of heavy metals contamination. Mar. Pollut. Bull. 48, 526-532.

Valdovinos, C., Zúñiga, M., 2002. Copper acute toxicity tests with the sand crab Emerita analoga (Decapoda: Hippidae): a biomonitor of heavy metal pollution in Chilean coastal seawater. Bull. Environ. Contam. Toxicol. 69, 393-400.

Van Straalen, N.M., Timmermans, M.J.T.N., 2002. Genetic variation in toxicant-stressed populations: an evaluation of the "genetic erosion" hypothesis. Hum. Ecol. Risk. Assess. 8, 983-1002.

Vannucci, M., 2001. What is so special about mangroves? Braz. J. Biol. 61, 599-603.

Wang, W.-X., Rainbow, P.S., 2005. Influence of metal exposure history on trace metal uptake and accumulation by marine invertebrates. Ecotoxicol. Environ. Saf. 61, 145-159.

Wang, W.-X., Rainbow, P.S., 2008. Comparative approaches to understand metal bioaccumulation in aquatic animals. Comp. Biochem. Physiol. 148C, 315-323.

Wright, S., 1943. Isolation by distance. Genetics 28, 114-138.

Zar, J.H., 1999. Biostatistical Analysis. fourth ed. Prentice Hall, Upper Saddle River, New Jersey.

Zhang, H., Shia, C., Yanga, H., Chena, G., Liu, D., 2016. Genotoxicity evaluation of ionic liquid 1-octyl-3-methylimidazolium bromide in freshwater planarian Dugesia japonica using RAPD assay. Ecotoxicol. Environ. Saf. 134, 17-22. 